Studia i Materiały, 2/2017 (25), cz. 2: 56-65

\title{
Odpowiedzialność karna członków zarządu w spółkach kapitałowych
}

\begin{abstract}
Aleksandra Polińska*
Przedmiotem niniejszego opracowania jest przybliżenie zasad odpowiedzialności członków zarzadu spótek kapitałowych. Autorka prezentuje podstawowe cele i zasady organu wykonawczego, tj. zarzadu, $i$ zwiazane z tym obowiazki spoczywajace na jego członkach. Naruszenie natożonych na nich obowiązów może prowadzić nie tylko do odpowiedzialności cywilnoprawnej, lecz także do odpowiedzialności karnej. Następnie przybliżone zostaja przestępstwa indywidualne, których podmiotem sa członkowie zarzadu wskazane w Kodeksie spótek handlowych, na podstawie których opisano zasady odpowiedzialności członków zarządu.
\end{abstract}

Słowa kluczowe: członkowie zarządu, odpowiedzialność karna, przestępstwa indywidualne.

Nadesłany: 31.01.17 | Zaakceptowany do druku: 30.11.17

\section{Criminal liability of board members}

The subject of this paper is to discuss the principles of responsibility of directors of companies. The author presents the basic objectives and principles of management and related obligations on its members. Violation of obligations imposed on them can lead not only to civil liability but also criminal liability. Then indicated crimes individual entity whose board members are specified in the Commercial Companies Code, based on the described principles of responsibility of board members.

Keywords: board members, criminal responsibility, individual crimes.

Submitted: 31.01 .17 | Accepted: 30.11 .17

JEL: K22

\section{Wstęp}

Przedmiotem niniejszego artykułu jest określenie odpowiedzialności karnej, jakiej podlegają członkowie zarządu w spółkach kapitałowych. Problematyka odpowiedzialności karnej za czyny popełnione w ramach funkcjonowania spółek prawa handlowego przez długi czas nie odgrywała znaczacej roli w praktyce. Dopiero zmiana systemu gospodarczego, dynamiczny wzrost aktywności różnego rodzaju spółek i nadanie im istotnego znaczenia w obrocie gospodarczym spowodowały wzrost praktycznego znaczenia przepisów normujących przestępstwa, związane właśnie z tą sferą

\footnotetext{
Aleksandra Polińska - mgr, Kancelaria Adwokacka Aleksandra Polińska w Płocku.

Adres do korespondencji: Kancelaria Adwokacka Aleksandra Polińska w Płocku, ul. Obejście 22B, 09-402 Płock, e-mail: aleksandra.polinska@onet.pl.
} 
działalności człowieka (Uljasz, 2002, s. 153). W ścisłym bowiem związku z założeniami regulacji działania spółek kapitałowych pozostają unormowania obowiązków i związanej z nimi odpowiedzialności członków zarządu spółki, oni to prowadzą sprawy spółki i reprezentuja ja na zewnatrz. Naruszenie nałożonych na nich obowiązków może prowadzić do odpowiedzialności członków zarządu, polegającej m.in. na obowiązku naprawienia wyrządzonej szkody, zapłaty cudzego długu, czy wykonania zobowiązania osoby trzeciej (Walerjan i Żak, 2010, s. 227). Rzecz w tym, że czynności dokonywane w imieniu tych podmiotów i na ich rzecz mogą także wyczerpywać znamiona czynów zabronionych. Pojawiać się wówczas może kwestia prawnokarnej oceny zachowań osób wchodzących w ich skład (Lachowski i Oczkowski, 2006, s. 25). Problematyka odpowiedzialności członków zarządu może mieć duże znaczenie przy ustaleniu zasad i „reguł gry”, jakie panuja w spółce (Hensel, 2015, s. 47-60). Ma ona również duży wpływ na decyzję o wyborze odpowiedniego modelu biznesowego (Kłobukowski i Pasieczny, 2016), a także w kontekście dysfunkcji organizacyjnych (Pasieczny i Glinka, 2016).

W pierwszej kolejności zaprezentowane zostana podstawowe funkcje i zadania, jakie realizuje zarząd spółki. Pozwoli to lepiej zrozumieć przepisy karne, którym podlegają członkowie zarządu. Zakres kolejnych norm prawnych zawartych w art. 586 i następ. ksh to nic innego jak kryminalizacja norm (zakazów) zawartych $\mathrm{w}$ określonych przepisach regulujących funkcjonowanie spółek handlowych i obowiązków, jakimi obarczeni są w tym zakresie członkowie zarządu. Celem takiego ustawodawstwa i wprowadzenia przepisów karnych była konieczność zapewnienia prawidłowej realizacji nałożonych na członków zarządu obowiązków - zarówno ustawą, umowa, jak i uchwałami zadań. To z kolei ma gwarantować prawidłowe funkcjonowanie obrotu gospodarczego. Chronione dobra prawne to także, m.in., majątkowe i niemajątkowe interesy spółek, interesy wspólników i akcjonariuszy czy interesy wierzycieli i osób trzecich (Walerjan i Żak, 2010, s. 230). Poniżej przedstawione zostana przepisy karne zawarte w kodeksie spółek handlowych, które zawierają tzw. przestępstwa indywidualne, obejmujące swoją normą właśnie członków zarządu.

\section{Funkcje i zadania członków zarządu w spółkach kapitałowych}

Zgodnie z przepisami kodeksu spółek handlowych ${ }^{1}$ do spółek kapitałowych zaliczamy spółkę z ograniczoną odpowiedzialnością oraz spółkę akcyjną. Oba te podmioty wyróżniają w swojej strukturze organizacyjnej organ o charakterze wykonawczym - zarząd spółki. W doktrynie podkreśla się, że zarząd jest organem spółki, który realizuje zdolność do czynności prawnych spółki. Zasady prowadzenia spraw spółki przez zarząd wieloosobowy ujęte są w przepisach art. $201 \S 1 \mathrm{ksh}$ i art. 208 § 2-8 ksh. Analogiczne w treści przepisy art. $368 \S 1$ ksh i art. $371 \S 1-5$ ksh dotyczą zarządu spółki akcyjnej z tą jednak różnicą, że zgodnie z art. $371 \S 1$ ksh statut może wyłączyć obowiązek prowadzenia spraw spółki przez danego członka zarządu (Lachowski i Oczkowski, 2006, s. 30).

Zgodnie z przepisami zarząd to organ, którego głównym zadaniem jest prowadzenie spraw spółki poprzez podejmowanie decyzji mających wpływ na jej funkcjonowanie i jej reprezentacje. Zasadnicze kompetencje zarządu wyznaczone w art. 201 $\S 1$ ksh sprowadzają się do prowadzenia spraw spółki oraz jej reprezentacji. Zarząd jest organem właściwym do podejmowania wszystkich decyzji niezastrzeżonych w przepisach ustawy oraz umowie spółki do kompetencji innych organów i z tego względu w przypadku zarządu mówimy o zasadzie domniemania kompetencji zarządu.

Reprezentacja spółki polega na działaniu zarządu, przedstawicieli ustawowych, pełnomocników, prokurentów, polegającym na składaniu i przyjmowaniu oświadczeń woli za spółkę lub w jej imieniu. Reprezentacja spółki odnosi się do działań podejmowanych w stosunkach zewnętrznych spółki. W myśl art. 204 ksh prawo członka zarządu do reprezentowania spółki obejmuje wszystkie czynności sądowe i pozasądowe spółki (Kidyba, 2013, s. 869-872).

Przez prowadzenie spraw spółki należy rozumieć podejmowanie decyzji we wszystkich sferach jej działania oraz decyzji przygotowujących lub wykonujących czynności prawne (Naworski, 2001, s. 393). W zakres pojęcia prowadzenia spraw spółki wchodzą też czynności o charakterze organizacyjnym. W ramach prowadzenia spraw spółki zarząd w przeważającej mierze dokonuje czynności o charakterze 
faktycznym (Kidyba, 2013, s. 870-871). Zgodnie z treścią przepisów art. 201 § 1 i $208 \S 2 \mathrm{ksh}$, z chwilą powołania zarządu, każdy z jej członków ma prawo i obowiązek prowadzenia spraw spółki. Obowiązku tego nie można wyłączyć w stosunku do niektórych członków zarządu, choć nie można przy tym wykluczyć podziału między nimi wykonywania prawnych czynności (Naworski, 2001, s. 395). Przepis ten jednak w żaden sposób nie zmienia generalnego obowiązku prowadzenia wszystkich spraw spółki przez każdego z członków zarządu. Co prawda wprowadzony do ksh art. 208 $\S 8$ przewiduje szczególne uprawnienia prezesa w zakresie głosu oraz daje możliwość przyznania mu szczególnych, innych uprawnień w umowie spółki. Przepis ten jednak w żaden sposób nie zmienia wskazanej wcześniej zasady, a więc należytego dbania o interesy spółki przez wszystkich członków zarządu, przez co należy rozumieć także wykonywania przez spółkę szczególnych obowiązków prawnych wynikajacych z przepisów prawa. Oznacza to, że brak jest przepisu prawnego, który przewiduje szczególne zasady odpowiedzialności w stosunku do prezesa zarządu. Jego pozycja w spółce ma z pewnością charakter uprzywilejowany, ale nie oznacza to ustawowego ograniczenia powinności należytego wykonywania obowiązków przez inne osoby wchodzące w skład zarządu (Lachowski i Oczkowski, 2006, s. 260).

Obowiązek prowadzenia bieżących spraw spółki przez wszystkich członków zarządu jest generalną zasadą. Status prawny członka zarządu ukształtowany został przez ustawodawce w sposób szczególny. Przy wykonywaniu swoich obowiązków powinien dokładać staranności sumiennego kupca. Uważa się przy tym, że objęcie tego stanowiska w danej spółce mimo braku wykształcenia lub wiadomości potrzebnych do prowadzenia jej spraw jest naruszeniem wymaganej staranności i sumienności ${ }^{2}$. Osoby wchodzące w skład tego organu są tymi osobami, które posiadają uprawnienia do rozporządzania majątkiem spółki, zaciągania zobowiązań, czyli dokonywaniach tych czynności, które wywołują skutki prawne w sferze majątkowej reprezentowanego podmiotu (Lachowski i Oczkowski, 2006, s. 27). To właśnie zarząd, z uwagi na posiadane uprawnienia i obowiązki, odpowiada za kondycję finansową spółki oraz za jej działanie zgodnie z prawem. Co więcej, zarząd powinien mieć także na względzie ochronę interesów majątkowych wierzycieli spółki. Naruszenie tego obowiązku i narażenie wierzycieli na szkode majątkowa $\mathrm{z}$ powodu wadliwego zarządu może skutkować odpowiedzialnościa członków zarządu za zobowiązania spółki, jak również odpowiedzialnością karną. Obowiązku tego nie można wyłaczyć lub ograniczyć w drodze odpowiednich postanowień umowy lub uchwał spółki (Lachowski i Oczkowski, 2006, s. 28-29).

\section{Odpowiedzialność karna czlonków zarządu w świetle przepisów kodeksu spółek handlowych (przestępstwa indywidualne)}

W związku z powyższym za niedopełnienie obowiązków, nienależyte ich wypełnienie czy wypełnienie niezgodnie $\mathrm{z}$ przepisami obowiazujacego prawa, członkowie zarządu podlegają odpowiedzialności karnej. W nauce prawa karnego czyn rozumiany jest jako zachowanie człowieka. Przenosząc to stwierdzenie na grunt rozważań o odpowiedzialności karnej członków kolegialnych organów spółek kapitałowych, trzeba stwierdzić, że prawnokarnemu wartościowaniu nie podlega zachowanie takiego gremium jako całości, lecz zachowanie jego poszczególnych członków (Lechowski i Oczkowski, 2006, s. 28). Odpowiedzialności karnej za przestępstwa indywidualne wskazane w ksh podlega każdy członek zarządu spółki kapitałowej, ponieważ należy przyjać, że wraz z przyjęciem funkcji członka zarządu osoba ta przyjmuje ogólne ustawowe obowiązki związane $\mathrm{z}$ tą funkcją (Zawłocki, 2013, s. 1479-1480). Cechą współczesnych systemów prawnych jest możliwość postawienia zarzutu popełnienia przestępstwa osobie fizycznej. Oznacza to, że tylko takie podmioty moga ponosić odpowiedzialność karną za swój czyn w granicach swojej winy (zasada indywidualizacji odpowiedzialności karnej) (Lachowski i Oczkowski, 2006, s. 25). Indywidualizacja odpowiedzialności członków zarzadu wynika $\mathrm{z}$ podstawowej zasady prawa karnego, jaką jest właśnie zasada indywidualizacji odpowiedzialności karnej (Czura-Kalinowska, 2014). Zdaniem R. Zawłockiego przestepstwo popełniają wszyscy członkowie zarządu, jednak 
ich odpowiedzialność jest indywidualna (Zawłocki, 2004, s. 1270).

Znany jest podział przestępstw według kryterium podmiotowości na przestępstwa powszechne (ogólne) i przestepstwa indywidualne (delictapropria) (Dermont, 2001, s. 72). W przypadku przestępstw indywidualnych (delictapropria) dyspozycja normy wymaga od sprawcy posiadania określonej właściwości i konstruuje typ przestępstwa w ten sposób, że tylko w razie posiadania tej właściwości określone w dyspozycji normy działanie sprawcy jest przestępstwem (Waszczyński, 1992, s. 115-116). Do najbardziej skonkretyzowanych podmiotów występków określonych przez kodeks spółek handlowych zaliczyć wypada m.in. właśnie członków zarządu. To ten organ najbardziej narażony jest na pozostanie podmiotem wystepku. Wystepuje on w art. 586 i n. ksh - określających przestępstwa oraz art. 594 i 595 ksh - określających naruszenie przepisów porządkowych (Dermont, 2001, s. 73)

W kodeksie spółek handlowych w tytule V Przepisy karne zawarte są normy określające poszczególne typy występków. Poniżej omówione zostaną przepisy karne zawarte $\mathrm{w}$ ksh oraz przedstawiona odpowiedzialność członków zarzadu za wybrane występki, które mogą znaleźć zastosowanie do członków zarządu spółek kapitałowych. W kolejnych przepisach 586-595 ksh znajdziemy przestępstwa, które można zakwalifikować jako przestępstwa na szkodę wspólników i wierzycieli spółki handlowej.

\subsection{Niezgłoszenie wniosku o upadłość spółki}

Zgodnie z art. 586 ksh kto, będac cztonkiem zarzadu spótki albo likwidatorem, nie zgtasza wniosku o upadtość spótki handlowej pomimo powstania warunków uzasadniajacych wedtug przepisów upadtość spótki podlega grzywnie, karze ograniczenia wolności albo pozbawienia wolności do roku.

Karnoprawną istotą rozważanego przestepstwa jest karalne niezgłoszenie wniosku o upadłość spółki handlowej w sytuacji, gdy spełnione zostały warunki uzasadniajacce konieczność dokonania takiej czynności (Zawłocki, 2013, s. 1475).

Odpowiedzialność wynikająca $\mathrm{z}$ tego przepisu ściśle wiąże się $\mathrm{z}$ prawnym obowiązkiem członków zarządu dołożenia należytej staranności w prowadzeniu spraw spółki oraz unikania wszelkich sytuacji, w której spółka, na skutek ich zawinionego zachowania, mogłaby ponieść szkodę. Do zakresu tych obowiązków w sposób oczywisty należy także obowiązek zgłoszenia wniosku o upadłość spółki. Jest to konieczne $\mathrm{z}$ uwagi na przesłanki formalne i materialne. Wskazany obowiazek jest na tyle istotny dla interesów spółki oraz jej wierzycieli, że ustawodawca opatrzył jego niedopełnienie sankcją karną.

Przepis ten dotyczy wszystkich spółek osobowych i kapitałowych, które prowadzą w celu zarobkowym i na własny rachunek działalność gospodarczą. Nie dotyczy on zatem tych spółek handlowych, które nie prowadzą działalności zarobkowej (np. spółki non profit albo fundusze emerytalne) lub nie prowadzą na własny rachunek działalności gospodarczej. Odpowiedzialność karna na podstawie analizowanego przepisu nie odnosi się do przedsiębiorców, co do których możliwość upadłości jest w ogóle wyłączona, np. państwowe i komunalne jednostki organizacyjne, NFZ, przedsiębiorstwa państwowe i inne (Zawłocki, 2013, s. 1476).

Jak wskazuje A. Dermont, istotą rozważanego przestępstwa nie jest zaprzestanie płacenia długów przez spółkę handlową (Dermont, 2001, s. 77). Oznacza to, że jakikolwiek ujemny bilans oraz zaprzestanie płacenia długów same przez się nie determinuja odpowiedzialności karnej. Odpowiedzialność karną na podstawie analizowanego przepisu można bowiem ponieść tylko wtedy, gdy w sposób faktyczny naruszy się ściśle określony obowiązek zgłoszenia upadłości. W ramach zarzutu popełnienia tego występku zachodzi bezwzględna konieczność ścisłego określenia i wykazania konkretnej przesłanki obligującej do zgłoszenia upadłości ${ }^{3}$. W doktrynie prezentowany jest pogląd, że znamiona przestępstwa z art. $586 \mathrm{ksh}$ zachodzą, gdy spełnione są dwie przesłanki, a mianowicie, gdy zachodzi stan niewypłacalności dłużnika ustalany na podstawie niewykonania przez dłużnika wymaganych zobowiązań oraz gdy niewypłacalność dłużnika oparta jest na ustaleniu, że zobowiązania dłużnika przekraczają wartość jego majątku, stanowiącą podstawę ogłoszenia upadłości. Według innego stanowiska do realizacji ww. ustawowych znamion wymagane jest istnienie trzech przesłanek, a mianowicie dodatkowo istnienie stanu, w którym niewykonanie zobowiązań ma charakter trwały 
oraz stanu, gdy majątek niewypłacalnego dłużnika jest wystarczający na zaspokojenie kosztów postępowania upadłościowego (Czura-Kalinowska, 2014, s. 1937).

Należy podzielić pogląd, że w sytuacji gdy zachodzą warunki do ogłoszenia upadłości, to zarząd lub likwidator - niezależnie od zwołania zgromadzenia wspólników celem podjęcia uchwały $\mathrm{w}$ tym przedmiocie - powinien złożyć w sądzie wniosek o ogłoszenie upadłości spółki (Skorupka, 2000, s. 33-34). Od odpowiedzialności $\mathrm{z}$ art. $586 \mathrm{ksh}$ nie zwalnia także sprawcy sytuacja, gdy osoba zobowiązana do złożenia wniosku nie złoży go, gdy stwierdzi, że zachodzi jedna $z$ sytuacji, które zobowiązują bądź uprawniają sąd upadłościowy do oddalenia wniosku o ogłoszenie upadłości. Należy pamiętać również o tym, że odpowiedzialność za naruszenie obowiązku zgłoszenia upadłości powstaje zarówno wtedy, gdy osoby, na których ciążył ten obowiązek, w ogóle nie wystąpiły z wnioskiem, jak i wówczas, gdy wniosek został złożony, lecz z przekroczeniem terminu określonego przez przepisy prawa upadłościowego do dokonania tej czynności (Czura-Kalinowska, 2014, s. 1937). Taka sama sytuacja powstaje, gdy zostanie złożony wniosek nieodpowiadający innym wymaganiom prawa upadłościowego i naprawczego albo zostaje nienależycie opłacony i w związku z tym zwrócony bez wzywania dłużnika o jego uzupełnienie lub opłacenie (Rodzynkiewicz, 2014, s. 1308). Zdaniem P. Pinior jako przestępstwo powinno być traktowane niezłożenie wniosku o ogłoszenie upadłości, a także zamierzone składanie wniosku niespełniającego wymogów formalnych. Nie jest natomiast - jego zdaniem - objęte penalizacją złożenie wniosku niespełniającego wymogów formalnych, jeżeli było to wynikiem działania niezamierzonego (Pinior, 2014, s. 1460).

Przepis art. 586 ksh nie będzie miał zastosowania $\mathrm{w}$ sytuacji, gdy przedsiębiorca złożył podania o otwarcie postępowania układowego. W tej sytuacji następuje zawieszenie biegu terminu do zgłoszenia wniosku o ogłoszenie upadłości. Złożenie podania uchyla zatem - przynajmniej tymczasowo - obowiązek zgłoszenia wniosku o upadłość (Uliasz, 2002, s. 156).

Jeśli przesłanki, którymi kieruje się na przykład dany członek zarządu, aby opóźnić decyzje o złożeniu wniosku o upadłość choć wątpliwe, są oparte na dowodach trudnych do zweryfikowania w danym momencie, może on zostać uwolniony od odpowiedzialności karnej bądź stopień jego zawinienia może ulec zmniejszeniu. To, że nieznajomość prawa nie zwalnia od odpowiedzialności, nie tłumaczy jednocześnie, że błędna ocena oparta na niepełnej wiedzy - w danej sytuacji usprawiedliwionej okolicznościami - może ją zastępować (Kidyba, 2015, s. 1502).

\subsection{Dopuszczenie do nabycia własnych udziałów lub akcji albo brania ich w zastaw}

Zgodnie z art. 588 ksh kto, będac cztonkiem zarzadu albo likwidatorem, dopuszcza do nabycia przez spótke handlowa wtasnych udziatów lub akcji albo brania ich $w$ zastaw podlega karze grzywny, karze ograniczenia wolności albo pozbawienia wolności do 6 miesięcy.

Karnoprawną istotą przestępstwa $\mathrm{z}$ art. $588 \mathrm{ksh}$ jest karalne dopuszczenie do nabycia przez spółkę handlową własnych udziałów lub akcji albo brania ich w zastaw.

Przestępstwo z art. 588 ksh jest przykładem kryminalizacji norm (zakazów) zawartych w określonych przepisach regulujących funkcjonowanie spółek handlowych. Kryminalizacja wskazanego zachowania wynika z następujących przesłanek:

1) Wskutek nabywania własnych akcji (udziałów) zmniejsza się rzeczywisty majątek spółki,

2) Uznanie prawa do nabycia własnych akcji (udziałów) doprowadziłoby do wykreowania faktycznie nowych form prawnych działalności gospodarczej, co jest niezgodne z zasada numerus clausus podmiotów prawa handlowego (CzuraKalinowska, 2014, s. 1940).

Uregulowanie zawarte w art. 588 ksh jest emanacją przepisu zawartego w art. 200 ksh, dotyczącym spółki z o.o. oraz w art. $362 \S 1$ i 2 ksh dotyczacego spółki akcyjnej. W literaturze niejednoznacznie przyjmuje się dopuszczalność stosowania tego przepisu do spółki komandytowo-akcyjnej. Zdaniem Zawłockiego przepis dotyczy także spółki komandytowo-akcyjnej (Zawłocki, 2013, s. 1496). Jednakże już M. Rodzynkiewicz wskazuje, że w odniesieniu do spółki komandytowoakcyjnej art. 588 ksh może mieć zastosowanie tylko wówczas, gdy chodzi o czynności dokonywane przez likwidatora takiej spółki, bowiem komplementariusz, który 
dopuścił się zakazanego nabycia akcji własnych nie jest członkiem zarządu spółki (Rodzynkiewicz, 2014, s. 1310). Z kolei P. Pinior zajmuje stanowisko, że w przypadku spółki komandytowo-akcyjnej do komplementariuszy stosuje się odpowiednio przepisy dotyczące członków zarządu, stosuje się przepisy dotyczące kapitału zakładowego i akcji. Trudno zatem przyjać, że przestępstwo to można popełnić tylko w spółce akcyjnej. De lege ferenda autor proponuje objąć przepisem także komplementariuszy (Pinior, 2015, s. 1464-1465). Artykuł 588 ksh nie określa samodzielnie w sposób zupełny i kompletny znamion typu czynu zabronionego, lecz celem ich ustalenia konieczne jest odwołanie się do treści art. 200 i 362 ksh. Przepisy te bowiem współokreślają łącznie $\mathrm{z}$ art. $588 \mathrm{ksh}$ zakres nabywania własnych udziałów lub akcji przez spółkę oraz ustawowy opis czynu zabronionego (Czura-Kalinowska, 2014, s. 1942). Mówiąc inaczej: przepisy te zawierają katalogi okoliczności wyłączających bezprawność zachowania się sprawcy (odpowiednio art. 200 § 4 ksh oraz 362 § 1 zd. 2 pkt 1-9 ksh) (Zawłocki, 2013, s. 1497).

Rozważany przepis kryminalizuje wyłącznie czynności odnoszące się do „własnych udziałów lub akcji”, co ogranicza krag potencjalnych sprawców wyłącznie do członków organu spółki-emitenta. Decyzje tego rodzaju w praktyce podejmowane sa kolegialnie (np. w formie uchwały zarządu). Karalne jest nie tylko podjeccie czynności potrzebnych do nabycia własnych udziałów lub akcji, lecz także świadomy i zamierzony brak sprzeciwu (Pinior, 2015, s. 1464). Członkowie zarządu (i likwidator) będa więc ponosić odpowiedzialność zarówno wtedy, gdy podejmą czynności zmierzające do nabycia przez spółkę własnych udziałów lub akcji, jak i w przypadku, gdy nie wyrażą wymaganej aktywności w celu przeciwdziałania takim czynnościom podejmowanym np. przez pozostałych członków zarządu, likwidatorów, czy nawet członków innych organów spółki (Uliasz, 2002, s. 158). Należy przy tym pamiętać, że przestępstwo to można popełnić wyłącznie umyślnie, z zamiarem bezpośrednim albo z zamiarem ewentualnym. Przestępny zamiar sprawcy polega tutaj łącznie na:

1) jego świadomości kodeksowych zakazów nabycia przez spółkę handlową własnych udziałów lub akcji albo brania ich w zastaw, oraz
2) jego woli dopuszczenia do naruszenia tych zakazów (Zawłocki, 2013, s. 1501).

\subsection{Bezprawne wydanie dokumentów na udziały lub prawa do zysków w spółce z o.o.}

Zgodnie z art. 589 ksh kto, będac cztonkiem zarzadu albo likwidatorem spótki $z$ ograniczona odpowiedzialnościa, dopuszcza do wydania przez spótke dokumentów imiennych, na okaziciela lub dokumentów na zlecenie na udziaty lub prawa do zysków $w$ spótce podlega grzywnie, karze ograniczenia wolności albo pozbawienia wolności do 6 miesięcy.

Karnoprawna istotą rozważanego przestępstwa jest karalne dopuszczenie do wydania przez spółkę z ograniczoną odpowiedzialnością określonych dokumentów na udziały lub prawa do zysków w tej spółce. Kryminalizacja tego zachowania wynika wprost z normy art. $174 \S 6 \mathrm{ksh}$. Stanowi on, że na udziały lub prawa do zysku w spółce nie moga być wystawiane dokumenty na okaziciela, jak również dokumenty imienne lub na zlecenie. Odpowiedzialność karna wynikająca z tego przepisu ma na ceku wzmocnienie ochrony zakazu wystawiania dokumentów udziałowych na okaziciela lub na zlecenie, inkorporujących prawa na udziały lub prawa do zysków dla potencjalnie każdego zainteresowanego, tj. anonimowość wspólników spółki z o.o. Konstrukcja sp. z o.o. opiera się bowiem na ścisłym powiazaniu udziału w tej spółce z określoną osobą. Anonimowość wspólników sp. z o.o. jest wykluczona, uniemożliwiałoby to bowiem m.in. unikanie ich odpowiedzialności osobistej za zobowiazania spółki (Zawłocki, 2013, s. 1501-1503). Spółka z o.o. jest wprawdzie spółką kapitałową, ale występują w niej elementy osobowe, wskazujące na istniejącą więź między spółką a wspólnikiem. Przejawem tego jest nie tylko art. $174 \S 6 \mathrm{ksh}$, ale także możliwość uzależnienia dopuszczalności zbycia udziału od zgody spółki (art. 182 ksh), czy też przysługujace wspólnikowi prawo kontroli (art. 212 \$ $1 \mathrm{ksh}$ ) (Uliasz, 2002, s. 158). Sankcjonowanie karne zakazu przewidzianego w art. $174 \S 6$ ksh uznano w doktrynie prawa handlowego za nieporozumienie, gdyż w istocie nie może dojść do naruszenia dobra prawnego, skoro na podstawie art. $176 \S 6 \mathrm{ksh}$ jakiekolwiek pisma stwierdzajace prawa udziałowe lub prawa dywidendowe mogą mieć wyłącznie charakter 
zaświadczeń, a nie papierów wartościowych (Kruczalak i in., 2001, s. 327).

Niedopuszczalne jest więc wystawienia jakichkolwiek dokumentów, które mogłyby ucieleśniać prawa udziałowe i prawa do zysku (Czura-Kalinowska, 2014, s. 1944-1945). W doktrynie pojawiają się także głosy, że sankcja karna dotyczy wydawania wymienionych dokumentów, a nie samego ich wystawienia. Natomiast czynności zmierzajace do wydania dokumentu innemu podmiotowi (np. jego wystawienie) mogą być podstawą odpowiedzialności karnej za usiłowanie popełnienia przestępstwa określonego w tym przepisie (Walerjan i Żak, 2010, s. 233-234). Nie oznacza to, że nie można wydawać zaświadczeń potwierdzających bycie wspólnikiem, co jednak nie powinno być odwzorowaniem księgi udziałów. Artykuł 589 ksh nie kryminalizuje zachowania sprawcy, gdy jego przedmiotem są tzw. świadectwa udziałowe, które tylko potwierdzają objęcie przez określony przedmiot udziału, ale nie ucieleśniaja w sobie jakichkolwiek praw majątkowych (Czura-Kalinowska, 2014, s. 1944-1945). Nie może być także mowy o popełnieniu przestępstwa określonego w art. 589 ksh wówczas, gdy zarząd spółki z ograniczoną odpowiedzialnością wydaje dokumenty tzw. obligacji partycypacyjnych, czyli takich, które przyznają obligatariuszowi prawo do udziału w zyskach emitenta, gdyż spółka z ograniczoną odpowiedzialnością jest wyraźnie upoważniona do emisji takich papierów wartościowych (zob. art. 19 ust. 2 ustawy o obligacjach) (Rodzynkiewicz, 2014, s. 1312).

Sprawcą przestępstwa może być członek zarządu lub likwidator, który wydał taki dokument, jak również członek zarządu, który nie przeciwstawił się takim czynnościom (Kidyba, 2015, s. 1507).

\subsection{Bezprawne wydanie akcji} nieoplaconych lub przed rejestracją

Art. 592. Cztonek zarzadu, który dopuszcza do wydania dokumentów akcji:

1) niedostatecznie optaconych,

2) przed zarejestrowaniem spótki,

3) $w$ przypadku podwyższenia kapitału zaktadowego - przed zarejestrowaniem podwyższenia - podlega grzywnie, karze ograniczenia wolności albo pozbawienia wolności do roku.

Karnoprawna istotą rozważanego przestępstwa jest karalne nieuprawnione wyda- nie przez członka zarządu spółki akcyjnej dokumentów akcji, z naruszeniem konkretnych zakazów ustawowych z ksh. Karalne jest tutaj w szczególności naruszenie zakazu wydania dokumentu akcji:

1. w pełni nieopłaconych, wynikającego $\mathrm{z}$ art. $335 \S 1 \mathrm{ksh}$,

2. przed zarejestrowaniem spółki, wynikajacego $\mathrm{z}$ art. $322 \mathrm{ksh}$,

3. przed zarejestrowaniem podwyższenia kapitału zakładowego, wynikajacego z art. 335 § 4 ksh (Zawłocki, 2013, s. 1522).

Zakaz wydawania akcji niedostatecznie opłaconych dotyczy jedynie akcji na okaziciela (art. $335 \$ 1 \mathrm{ksh}$ ). Akcje imiennie mogą być wydawane przed pełną wpłatą (art. 335 \& 2 ksh). Wydanie dokumentów akcji, które są niedostatecznie opłacone może spowodować, że nie będzie możliwe wyegzekwowanie wpłat na akcje. Wydanie akcji w tej sytuacji powoduje zagrożenie dla obrotu. Nie są one jeszcze prawami pewnymi (Czura-Kalinowska, 2014, s. 1951-1952).

Występku z art. 592 ksh dokonuje więc członek zarządu, który dopuszcza do wydania akcji przed zarejestrowaniem spółki lub przed zarejestrowaniem podwyższenia kapitału zakładowego. Dotyczy to również sytuacji, gdy członek zarządu dopuszcza do wydania akcji nienależycie opłaconych (Uliasz, 2002, s. 160).

Czynność dopuszczenia do wydania dokumentów akcji oznacza każde zachowanie się sprawcy, w wyniku którego nastąpiło fizyczne przekazanie (odebranie) dokumentu akcji przez osobę trzecią, w sytuacjach opisanych w pkt 1-3 ww. przepisu. $\mathrm{Z}$ literalnego brzemienia przepisu wyniku, że karalne jest wydanie co najmniej dwóch dokumentów akcji (Czura-Kalinowska, 2014, s. 1953).

Rozważana norma prawnokarna odnosi się wyłącznie do spółki akcyjnej, nie odnosi się do publicznej spółki akcyjnej, co wynika $\mathrm{z}$ art. 328 par $6 \mathrm{ksh}$. W przypadku tej spółki nie dochodzi bowiem do wydania dokumentów z akcji (Zawłocki, 2013, s. 1522-1523). Rozważana norma nie dotyczy także spółki komandytowo-akcyjnej, mimo że także w tej spółce emituje się akcje, których dokumenty mogą być nieprawidłowo wydawane. W spółce komandytowo-akcyjnej nie ma jednak zarządu, a wykładnia rozszerzająca jest niedopuszczalna (Rodzynkiewicz, 2014, s. 1316) ${ }^{4}$. Zdaniem M. Rodzynkie- 
wicza przepis art. $592 \mathrm{ksh}$ nie odnosi sie także do likwidatora wobec jasnego brzmienia przepisu i zakazu wykładni rozszerzającej na niekorzyść (Rodzynkiewicz, 2014, s. 1316). Odmiennie stanowisko zajmuje tutaj A. Kidyba, który uważa, że pogląd ten nie jest trafny, ponieważ niewątpliwie art. 592 ksh jest przepisem dotyczącym członka zarządu, ale przecież w ogólności przepisy o członkach zarządu stosujemy odpowiednio do likwidatorów z mocy odesłania zawartego w art. 466 ksh (Kidyba, 2015, s. 1511).

\subsection{Wlaściwość rzeczowa \\ i przepisy porządkowe}

Przepisy zawarte w tytule V Przepisy karne w kodeksie spólek handlowych zawierają przepisy karne, zawierające tzw. sankcje kryminalne, pozostajace $\mathrm{w}$ kompetencji sądów rejonowych (art. 593 ksh). Sa również dwa inne przepisy, art. 594 i 595 ksh należące do właściwości rzeczowej sądów rejestrowych. Istota tych przepisów jest karalne naruszenie określonych obowiązków informacyjnych przez członków zarządu spółki handlowej, komplementariusza oraz jej likwidatora. Przepisy te nie określają ani przestępstw, ani też wykroczeń, lecz przewinienia o charakterze dyscyplinarnym. Postępowanie co do tych przewinień przeprowadza sąd rejestrowy, on też orzeka karę dyscyplinarną. W tym przypadku grzywna orzekana przez sąd rejestrowy ma tutaj charakter grzywny przewidzianej w Krajowym Rejestrze Sądowym i podlega ona reżimowi przepisów kpc. Nie ma ona charakteru sankcji karnej, lecz szczególnego pozapenalnego środka prawnego przymusu (Zawłocki, 2013, s. 1529-1530).

\section{Podsumowanie}

Kodeks kryminalizuje odpowiedzialność członków zarządu, ponieważ to na tym organie spoczywa duży ciężar w zakresie realizacji nałożonych na nich obowiązków. Przestępstwa $z$ tej grupy sankcjonują niewykonywanie obowiązków (zaniechanie) czy też działanie w sposób sprzeczny z nałożonymi na nimi obowiązkami. Odpowiedzialność karna, jakiej podlegają członkowie zarządu ma przede wszystkim na celu niedopuszczenie do sytuacji działania na szkode spółki przez organy zobowiazane ustawowe i, umownie, do dbania o jej inte- resy gospodarcze. $\mathrm{Z}$ całą stanowczością należy stwierdzić, że przepisy karne zawarte w ksh mogą stanowić skuteczny instrument pozwalający na zwalczanie patologicznych zjawisk w działalności spółek handlowych (Uliasz, 2002, s. 162). Jest to rozwiązanie niezwykle rzadko spotykane w praktyce, gdyż ewentualne działania sprzeczne z prawem czy zaniechanie w zakresie realizacji przez członków zarządu określonych obowiązków i roszczenia $\mathrm{z}$ tego wynikające rozwiązywane są $\mathrm{w}$ ramach postępowania cywilnego. Tymczasem wydaje się, że droga postępowania karnego jest i szybsza i skuteczniejsza, a dzięki określonym instytucjom pozwala - obok uzyskania ewentualnego wyrok skazującego - zaspokoić także (jednocześnie) roszczenia cywilnoprawne (naprawienie szkody). Jest to również rozwiązanie o wiele tańsze aniżeli dochodzenie roszczeń na drodze cywilnoprawnej, nie jest bowiem obarczone opłatami związanymi z wszczęciem postępowania, albowiem są to przestepstwa ścigane $z$ urzędu przez urzad prokuratorski. Oczywiście należy pamiętać o tym, że z samej istoty prawa karnego wynika, że nie jest możliwa odpowiedzialność karna tylko na tej podstawie, że ktoś jest członkiem zarządu. Odpowiedzialność karna należy zawsze rekonstruować w oparciu o indywidualne faktyczne zachowanie każdego z członków organu kolegialnego (Zawłocki, 2013, s. 1499), wypełniajace znamiona strony podmiotowej i przedmiotowej czynu zabronionego. W doktrynie prawa karnego przyjmuje się, że jest możliwe współsprawstwo przy tego typu przestępstwach, co niekiedy będzie oczywiste w przypadku decyzji podjettych kolegialnie. Oznacza to, że za niewłaściwe wykonywanie obowiązków zwiazanych z należytym prowadzeniem spraw spółki mogą odpowiadać jako współsprawcy wszyscy członkowie zarządu spółki. Podkreślić przy tym należy, że przy szczególnym obowiązku prawnym sankcjonowanym norma prawa karnego problem odpowiedzialności karnej wszystkich osób wchodzących w skład kolegialnego organu może nie powstać, jeżeli ten obowiązek został powierzony indywidualnie określonej osobie, będącej członkiem zarządu spółki (Lachowski i Oczkowski, 2006, s. 30). Wydaje się jednak, że w każdym przypadku należy analizować możliwość postawienia zarzutu wszystkim członkom zarządu, gdyż przecież na każdym z nich spoczywa obowią- 
zek należytego dbania o interesy spółki. Ewentualne wyłączenie odpowiedzialności karnej danego członka zarządu może nastąpić tylko w sytuacji dokonania dodatkowych ustaleń faktycznych, np. w przypadku szczegółowego podziału zadań między poszczególnych członków zarządu, czy też statutowego postanowienia w spółce akcyjnej, wyłączającego obowiązek prowadzenia i jej reprezentowanie, co w konsekwencji ma na celu zapewnienie prawidłowego obrotu jej spraw przez daną osobe (Lachowski i Oczkowski, 2006, s. 31-32). Okolicznościami wyłączającymi odpowiedzialność będzie także sytuacja, gdy członek zarządu złożył rezygnację $\mathrm{z}$ pełnienia funkcji członka zarządu ( $\mathrm{z}$ tą chwilą wygasa mandat), odwołanie członka zarządu przed upływem kadencji, jak i zawieszenie członka zarzadu w pełnieniu ww. funkcji (Czura-Kalinowska, 2014, s. 1942). Okolicznością wyłączającą odpowiedzialność nie będzie za to nieznajomość przepisów z ksh (i innych). Przyjmując funkcje członka zarządu lub likwidatora, przyjmują oni jednocześnie wszystkie obowiązki prawne związane $\mathrm{z}$ tą funkcją. Istnieje zatem tutaj domniemanie znajomości przepisów prawa. Należy jednak pamiętać, że domniemanie to jest dopiero wstępnym etapem przypisania takiej osobie zamiaru przestępnego (Zawłocki, 2013, s. 1504-1505). Konieczna jest zawsze szczegółowa analiza wypełnienia przez sprawcę/sprawców znamion przedmiotowych i podmiotowych danego przestępstwa. Stronę podmiotową zachowania się członków zarządu należy rozpatrywać w świetle przepisu art. 483 § 2 ksh, zgodnie z którym członek zarządu powinien przy wykonywaniu swoich obowiązków dołożyć staranności wynikającej z zawodowego charakteru swojej działalności. Oznacza to, że na podstawie samego sprawowania funkcji członka zarządu należy domniemywać jego wyższą od przeciętnej świadomość i wiedzę o swoich czynnościach, a także niemożność powoływania się np. na statut spółki lub regulamin zarządu. Karalne jest tutaj zachowanie będące wyrazem świadomej woli sprawcy. Wykazanie takiej okoliczności w ramach funkcjonowania sprawcy w strukturach kolegialnego zarządu wymaga dokładnego przedstawienia zachowania sie sprawcy, na podstawie którego można dopiero rekonstruować jego nastawienie psychiczne (zamiar). Spełnienie tego warunku wydaje się bardzo trudne, albowiem decyzje zarządu często zapadają większością głosów, realizują decyzje innych organów i podejmowane są często jednocześnie w odniesieniu do wielu spraw (Zawłocki, 2013, s. 1527-1528).

Kończąc, należy pamiętać, że obowiązki nałożone na członków zarządu nie mają charakteru zamkniętego i mogą mieć charakter szczególny. Dotyczy to np. sankcjonowanego w art. 77 kks wykonywania przez spółkę obowiązków płatnika podatku lub charakteru ogólnego, np. gdy chodzi o obowiązki związane $\mathrm{z}$ należytą dbałością o interesy majątkowe i niemajątkowe spółki, gdzie naruszenie tego obowiązku sankcjonowane jest np. w przepisach art. 296 k.k. lub 586 i następne ksh. Oznacza to, że przepisy karne, które mogą znaleźć zastosowanie do odpowiedzialności członków zarządu, zawarte sa nie tylko w kodeksie spółek handlowych, lecz także w kodeksie karnym, kodeksie karnym skarbowym, kodeksie wykroczeń, kodeksie pracy, ustawie o rachunkowości oraz innych aktach prawnych. Omówienie wszystkich regulacji, które mogłyby znaleźć zastosowanie do odpowiedzialności karnej członków zarządu zdecydowanie wykracza poza ramy niniejszego opracowania. Warto jednak o tym pamiętać. Odpowiedzialność karna jest bowiem istotnym elementem związanym $\mathrm{z}$ pełnieniem funkcji członka zarządu, o którym menedżerowie nie mogą zapominać, podejmując określone decyzje (Walerjan i Zak, 2010, s. 227).

Analiza przepisów karnych w zakresie przestepstw indywidualnych zawartych w kodeksie spółek handlowych niewątpliwie prowadzi do wniosków de lege ferenda w zakresie jednoznacznego określenia odpowiedzialności także w stosunku do likwidatorów i komplementariuszy. Autorka niniejszego opracowania nie podziela stanowiska, że przepisy karne określające przestępstwa indywidualne, gdzie podmiotem jest zarząd spółki, można stosować odpowiednio do likwidatorów i komplementariuszy poprzez odesłanie czy jakąkolwiek analogię. Przepisy karne zawsze należy interpretować zgodnie $\mathrm{z}$ ich literalną, jasną, zawężającą wykładnią. Wykładnia rozszerzajaca jest tutaj niedopuszczalna. Skoro mowa jest jedynie o członkach zarządu, a w spółce komandytowo-akcyjnej zarządu nie ma, to przepisy karne nie odnoszą się do tej spółki prawa handlowego. Skoro norma karna 
nie wymienia także likwidatora, to również w tym przypadku stosowanie przepisu karnego jest niemożliwe. Powstaje więc swoista luka prawna, którą z całą pewnością należałoby uzupełniać o stosowne zapisy ustawowe.

\section{Przypisy}

1 Ustawa z dnia 15 września 2000 r. Kodeks spółek handlowych Dz. U. 2016.1578 t.j.

2 Wyrok SN z dnia 6 czerwca 1997 r., III CKN 65/97, OSP 1998, nr 1, poz. 6.

3 Postanowienie SN z 13.06.2012 r., V KK 434/11.

4 Stanowisko to nie jest jednolite, a w doktrynie pojawiają się zdania, że przepis ten znajduje zastosowanie również do spółki komandytowoakcyjnej (tak: Kukuła, 2007, s. 39).

\section{Bibliografia}

Czura-Kalinowska, D. (2014). W: Z. Jara (red.), Kodeks spótek handlowych. Komentarz. Warszawa: C.H. Beck.

Dermont, A. (2001). Przestępstwa gospodarcze w kodeksie spółek handlowych - wybrane zagadnienia. Prokuratura i Prawo, 10.

Hensel, P. (2015). Wykorzystanie koncepcji konkurujących logik instytucjonalnych w badaniach organizacji. Organizacja i Kierowanie, 168, 47-60.

Kidyba, A. (2015). Kodeks spótek handlowych. Tom II, Komentarz do art. 301-633 k.s.h. Warszawa: Wolters Kluwer Polska.

Kidyba, A. (2013). Prawo spótek. Warszawa: Wolters Kluwer Polska.

Kłobukowski, P. i Pasieczny, J. (2016). Business models of startups in cooperation with mature companies - obtaining orders and building leading position on the market. Zeszyty Naukowe Politechniki Poznańskiej, 68, 61-77.

Kukuła, Z. (2007). Obostrzenia w obrocie akcjami i udziałami spółek kapitałowych a odpowiedzialność karna. Prawo Spótek, 11.

Lachowski, J. i Oczkowski, T. (2006). Odpowiedzialność karna członków kolegialnych organów spółek kapitałowych - zagadnienia wybrane. Prokuratura i Prawo, 2.

Naworski, J.P. (2001). W: Komentarz do kodeksu spótek handlowych. Spótka z ograniczona odpowiedzialnościa. Warszawa.

Pasieczny, J. i Glinka, B. (2016). Organizational Dysfunctions: Sources and Areas. Enterpreneurial Business and Economics Review, 4(4), 213-223.

Pinior, P. (2015). W: J.A., Strzępek (red.), Kodeks spótek handlowych. Komentarz. Warszawa: C.H. Beck.

Kruczalak, K. i in. (2001). Kodeks spótek handlowych. Komentarz. Warszawa: C.H. Beck.

Rodzynkiewicz, M. (2014). Kodeks spótek handlowych. Komentarz. Warszawa: C.H. Beck.

Skorupka, J. (2000). Odpowiedzialność członków władz kapitałowych w stosunku do wierzycieli. Prawo Spótek, 7-8.

Uliasz, M. (2002). Przepisy karne w KSH. Monitor Prawniczy, 4,

Walerjan, D. i Żak, T. (2010). Odpowiedzialność członków zarzadu spótek kapitałowych oraz praktyczne sposoby jej ograniczenia. Warszawa: Difin.

Waszczyński, J. (1992). Prawo karne $w$ zarysie. Nauka o ustawie karnej i przestępstwie. Łódź: Wydawnictwo Uniwersytetu Lódzkiego.

Zawłocki, R. (2013). W: Kodeks spótek handlowych, Komentarz. Warszawa: C.H. Beck. 